\title{
Crianças pequenininhas, relações de gênero e a produção das culturas infantis
}

\section{Vivian Colella Esteves (IC)}

\section{Resumo}

A presente pesquisa de iniciação cientifica teve como objetivo apresentar o processo de construção dos estereótipos do feminino e masculino nas pedagogias desenvolvidas na CAS - Creche da Área da Saúde da Unicamp, problematizando algumas práticas pedagógicas das professoras com crianças de 2 e 3 anos de idade.

Palavras Chave: Relações de gênero, creche, culturas infantis.

\section{Introdução}

A partir dos pressupostos teóricos dos estudos sobre as relações de gênero (SCOTT, 1999) ${ }^{1}$, do feminismo (BUTLER, 2003) ${ }^{2}$ da pedagogia da educação infantil e da sociologia da infância (FINCO \& FARIA, 2011) ${ }^{3}$, analisamos de que modo os meninos $\mathrm{e}$ as meninas percebem, reproduzem e resistem a imposição normativa referentes a construção binaria da masculinidade e feminidade. Trata-se de uma pesquisa com abordagem etnográfica realizada com crianças pequenininhas entre dois e três anos de idade $\mathrm{e}$ suas professoras. A pesquisa utilizou como instrumentos metodológicos observações na creche além de pequenas intervenções, que consistiam em um jogo de cartas de baralho e três contações de história. Por meio dos registros em diário de campo, vídeo e áudio foi possível problematizar alguns episódios e discutir temas como o sexismo, a heteronormatividade, o racismo e o padrão de beleza.

\section{Resultados e Discussão}

Com base nos dados coletados durante a pesquisa de campo podemos perceber que existe uma reprodução das desigualdades nas relações de gênero e nas práticas pedagogicas desenvolvidas com as crianças na CAS, por vivermos num contexto machista as docentes também são vítimas dessas opressões que estão dentro do sistema que alicerça as hierarquizações das diferenças. Essas opressões de gênero sobre a criança estão imbrincadas com

\footnotetext{
1 SCOTT, Joan. Gênero: uma categoria útil para análise histórica.

In:http://disciplinas.stoa.usp.br/pluginfile.php/6393/mod resource/co ntent/1/G\%C3\%AAnero-Joan\%20Scott.pdf> Acessado em: 10 de mar de 2014.

2 BUTLER, Judith. Sujeitos do sexo/gênero/desejo. In: Problemas de gênero. Rio de Janeiro: Civilização Brasileira, 2003. p 17 - 37.

3 FINCO, Daniela \& FARIA, Ana Lúcia Goulart de (Orgs.). Sociologia da infância no Brasil. Campinas, SP: Autores Associados, 2011. Coleção polêmicas do nosso tempo.
}

outras questões, pois as opressões não se dão de formas isoladas. Como defende o Feminismo interseccional é necessário também levar em conta a raça, etnia, classe, idade, religião, entre outras (CRENSHAW, 2002) ${ }^{4}$. O entendimento das opressões de modo interseccional aponta para uma desconstrução e combate das opressões de forma geral, não basta acabar com a opressão de classe, se ainda existe opressão de gênero e vice-versa, não basta acabar com o racismo, se ainda existe opressão de gênero e vice versa.

\section{Conclusões}

Ao final da pesquisa percebemos a necessidade de pensar práticas pedagógicas para desconstruir e não reproduzir esses estereótipos, romper com os paradigmas de gêneros de modo que este não se torne um aspecto limitante das construções subjetivas dos sujeitos.

\section{Agradecimentos}

Agradeço a orientação da Ana Lúcia Goulart de Faria.

Agradeço ao Flávio Santiago pela leitura e acompanhamento da pesquisa.

Agradeço ao grupo de pesquisa GEPEDISC Linha Culturas Infantis.

Agradeço a toda equipe da CAS.

Agradeço a todxs amigxs presentes na luta contra as opressões.

Agradeço ao CNPQ/ PIBIC. 